\title{
Synthesis, FTIR Studies and Optical Properties of Aluminium Doped Chromium Oxide Nanoparticles by Microwave Irradiation at Different Concentrations
}

\author{
J. T. Anandhi ${ }^{1, *}$, S. L. Rayer ${ }^{2}$, T. Chithambarathanu ${ }^{3}$ \\ ${ }^{1}$ Department of Physics, St. Jerome's College, India \\ ${ }^{2}$ Department of Physics, St. Jude's College, India \\ ${ }^{3}$ Department of Physics, S.T. Hindu College, India
}

Copyright $\bigcirc 2017$ by authors, all rights reserved. Authors agree that this article remains permanently open access under the terms of the Creative Commons Attribution License 4.0 International License

\begin{abstract}
In this exposure, pure and aluminium ( $\mathrm{Al})$ doped chromium (III) oxide $\left(\mathrm{Cr}_{2} \mathrm{O}_{3}\right)$ nanoparticles are synthesized by simple solvothermal microwave irradiation (SMI) technique. SMI technique is simple and low cost; it has the future to be produced on a huge scale. The effect of dopant $(\mathrm{Al})$ concentration on the structural behavior of $\mathrm{Cr}_{2} \mathrm{O}_{3}$ nanoparticles was examined by $\mathrm{X}$-ray diffraction. The average crystallite size of the synthesized nanoparticles was measured from XRD patterns using Scherrer equation and was decreased from $14.56 \mathrm{~nm} 10.86 \mathrm{~nm}$ with the increasing $\mathrm{Al}$ concentration in $\mathrm{Cr}_{2} \mathrm{O}_{3}$ from 0 to $5 \%$ (in steps of $0,1,2,3$, 5). Morphologies and compositional elements of the synthesized nanoparticles were observed by the field emission scanning electron microscopy (FESEM) and energy dispersive X-ray (EDX) spectroscopy, respectively. The optical property of the samples was measured by ultraviolet - visible (UV-Vis.) absorption spectroscopy. The observed optical band gap value ranges from $2.12 \mathrm{eV}$ to 1.90 $\mathrm{eV}$ for $\mathrm{Al}$ doped nanoparticles and was red shifted in comparison with that of the pure $\mathrm{Cr}_{2} \mathrm{O}_{3}(3.483 \mathrm{eV})$.
\end{abstract}

Keywords $\mathrm{Cr}_{2} \mathrm{O}_{3}$ Nanoparticles, SMI Method, Structural Properties, Optical Properties

\section{Introduction}

Nanotechnology is a branch of science which is meant to understand the fundamental physical and chemical properties and the phenomenon of nanomaterials and nanostructures and because of novel application of nanomaterials [1,2]. The application of nanomaterials utilizes not only chemical composition but also the size, shape and surface dependent properties [3]. Nanoparticles can be noncyrstalline, polycrystalline or single crystalline and can be produced with a variety of methods [4]. For the past years, enormous progress in the properties of naonparticles has been achieved. Nanomaterials, especially transition metal oxides play a specific role in the areas of physics, materials science and chemistry [5]. Synthesis of nanomaterials with desired morphology and composition is the most challenging task in the field of nanotechnology. The synthesis of metal oxides nanostructures have stimulated the great interest because of their novel properties which offers intensive research efforts to fabricate the efficient miniaturized devices for the applications in various nanoelectronics and photononics $[6,7$, 8]. Mostly metal oxides as nanoparticles can exhibit unique chemical properties due to their limited size and high density of corner or edge surface sites [9]. Chromium (III) oxide $\left(\mathrm{Cr}_{2} \mathrm{O}_{3}\right)$ nanoparticles have received special attention than the other metal oxide nanomaterials, because of multiple applications including green pigments [10], heterogenous catalyst [11-13], coating materials for thermal properties [14, 15], solar energy collector [16] digital recording system[17]. Because of the high energy density and high capacity at low discharge rates, chromium oxides have been attracted special attention used as cathode materials [18]. A variety of fabrication techniques have been explored in the literature for the synthesis of these metal oxide nanostructures but typically, they can be divided into two categories [19]. Metal oxide nanoparticles are considered to have the potency to generate reactive oxygen species. Band structure is the fundamental material property that controls ROS - producing ability, band turning via introduction of dopants [20]. Meanwhile, doping with selective elements to metal oxides offers an effective method to enhance and control the electrical and optical properties of metal oxide structures [21]. A number of chemical methods of synthesis have been applied to synthesis $\mathrm{Cr}_{2} \mathrm{O}_{3}$ powders, for example hydrothermal [22], thermal decomposition [23].

As per green chemistry principles water as an inexpensive, 
non-toxic, non-flammable and abundant material in nature, is a safer and ideal solvent for microwave - activated reactions [24-25].

In our study, pure and $\mathrm{Al}$ doped $\mathrm{Cr}_{2} \mathrm{O}_{3}$ nanoparticles are synthesized under microwave irradiation using triethanolamine as template and water as a green solvent aqueous solution of Aluminium nitrate is used in different concentration at different temperatures to study the effect of concentration in the synthesis of doped nano particles. Synthesis of $\mathrm{Al}$ doped $\mathrm{Cr}_{2} \mathrm{O}_{3}$ nanoparticles via the microwave irradiation could be worthwhile investigating.

In this paper, we report synthesis of pure $\mathrm{Cr}_{2} \mathrm{O}_{3}$ and $\mathrm{Al}$ doped $\mathrm{Cr}_{2} \mathrm{O}_{3}$ nanoparticles by microwave irradiation and its characterization by means of X-ray diffraction (XRD), scanning electron microscope (SEM), UV- Vis and FTIR spectroscopic methods which will give much valuable information about these materials.

\section{Materials and Methods: Experimental Procedure}

\section{Synthesis of Pure $\mathrm{Cr}_{2} \mathrm{O}_{3}$ Nanoparticles}

$25 \mathrm{ml}$ of $\mathrm{Cr}\left(\mathrm{NO}_{3}\right)_{3} \cdot \mathrm{H}_{2} \mathrm{O}(0.2 \mathrm{M})$ aqueous solution was mixed with appropriate amount of triethanolamine as template $(5 \mathrm{ml})$. After stirring for 30-40 minutes, the mixture was placed under microwave irradiation for 4 minutes. The green solid product was filtered and dried in air at room temperature. The materials were calcinated in electronic oven at $200^{\circ} \mathrm{C}$, for 1 hour followed by annelation at $500^{\circ} \mathrm{C}$, $700^{\circ} \mathrm{C}$ and $900^{\circ} \mathrm{C}$.

\section{Synthesis of Al doped $\mathrm{Cr}_{2} \mathrm{O}_{3}$ Nano Particles}

Aqueous solution of $\mathrm{Cr}\left(\mathrm{NO}_{3}\right)_{3} \cdot \mathrm{H}_{2} \mathrm{O}(0.2 \mathrm{M})$ was mixed with aqueous solution of aluminium nitrate $\mathrm{Al}\left(\mathrm{NO}_{3} \cdot \mathrm{H}_{2} \mathrm{O}\right)$ and appropriate amount of triethanolamine as template (5 $\mathrm{ml})$. After stirring for 30-40 minutes, the mixture was placed under microwave irradiation for 4-7 minutes. The green solid product was filtered and dried in air at room temperature. The materials were calcinated in electronic oven at $200^{\circ} \mathrm{C}$, for 1 hour followed by annelation. $99 \%$ of aqueous solution of chromium nitrate and $1 \%$ of aluminium nitrate yielded $1 \%$ $\mathrm{Al}$ doped $\mathrm{Cr}_{2} \mathrm{O}_{3}$ nanoparticles. $98 \%$ of aqueous solution of chromium nitrate and $2 \%$ of aluminium nitrate yielded $2 \%$ $\mathrm{Al}$ doped $\mathrm{Cr}_{2} \mathrm{O}_{3}$ nanoparticles. $97 \%$ of aqueous solution of chromium nitrate and $3 \%$ of aluminium nitrate yielded $3 \%$ $\mathrm{Al}$ doped $\mathrm{Cr}_{2} \mathrm{O}_{3}$ nanoparticles. $95 \%$ of aqueous solution of chromium nitrate and $5 \%$ of aluminium nitrate yielded $5 \%$ $\mathrm{Al}$ doped $\mathrm{Cr}_{2} \mathrm{O}_{3}$ nanoparticles.

\section{Results and Discussion}

\section{X-ray Diffraction Analysis}

X-ray diffraction (XRD) patterns were collected with an Goniometer 3000 powder X-ray diffractometer using $\mathrm{Cu} \mathrm{K \alpha}$ radiation source $(\lambda=1.540598 \AA$ ), germanium crystal monochromator, at room temperature $25^{\circ} \mathrm{C}$, curved position sensitive detector operating at $30 \mathrm{kV}$ and $30 \mathrm{~mA}$. Powder samples were loaded into a sample holder, and each pattern was collected for up to $2 \mathrm{~h}$ to obtain sufficiently high signal-to-noise ratio.

Figure 1 shows the XRD pattern of pure $\mathrm{Cr}_{2} \mathrm{O}_{3}$ nanoparticles prepared by $\mathrm{Cr}\left(\mathrm{NO}_{3}\right)_{3} 9 \mathrm{H}_{2} \mathrm{O}$ as the chromium source after annelation at $900^{\circ} \mathrm{C}$. Based on the XRD pattern, whereas the prepared sample calcined at $200^{\circ} \mathrm{C}$ proved to be amorphous. The crystallinity of the sample annealed at 900 ${ }^{\circ} \mathrm{C}$ was found to be much better than that annealed at $500{ }^{\circ} \mathrm{C}$ or $700{ }^{\circ} \mathrm{C}$. The average crystallite sizes (D) was calculated using well known Scherrer's equation

$$
\mathrm{D}=0.9 \lambda /(\beta \cos \theta)
$$

where $\lambda$, is the $\mathrm{x}$-ray wavelength used in $\operatorname{xrd}\left(1.540 \mathrm{~A}^{\circ}\right), \beta$ and $\theta$ are the full width at half maxima (FWHM) of the diffraction peak and the Bragg's diffraction angle respectively. The calculated average crystal size of pure (undoped) $\mathrm{Cr}_{2} \mathrm{O}_{3}$ nanoparticles using the above formula based on Table 1 was $14.56 \mathrm{~nm}$ and it was compared with previous studies reported as $14.82 \mathrm{~nm}$ [26]. The x-ray diffraction plots of $1 \%, 2 \%, 3 \%, 5 \%$ Al doped $\mathrm{Cr}_{2} \mathrm{O}_{3}$ are shown in figures 2-5. The crystal average size of aluminium doped $\mathrm{Cr}_{2} \mathrm{O}_{3}$ nanoparticles were calculated based on the Tables 2-5.

Table 1. Peak list with their relative intensity of $\mathrm{XRD}$ of pure $\mathrm{Cr}_{2} \mathrm{O}_{3}$

\begin{tabular}{|c|c|c|c|c|}
\hline Pos. [ ${ }^{\circ}$ 2Th.] & Height [cts] & FWHM Left [ ${ }^{\circ}$ 2Th.] & d-spacing $[\AA]$ & Rel. Int. [\%] \\
\hline $24.51(1)$ & $60(8)$ & $0.20(4)$ & 3.62868 & 55.75 \\
\hline $33.602(7)$ & $82(7)$ & $0.21(2)$ & 2.66494 & 76.23 \\
\hline $36.211(6)$ & $95(9)$ & $0.19(2)$ & 2.47870 & 89.22 \\
\hline $41.49(2)$ & $29(6)$ & $0.24(5)$ & 2.17477 & 27.45 \\
\hline $50.23(1)$ & $47(9)$ & $0.18(5)$ & 1.81479 & 44.10 \\
\hline $54.865(7)$ & $107(10)$ & $0.20(3)$ & 1.67201 & 100.00 \\
\hline $58.41(9)$ & $8(10)$ & $0.2(2)$ & 1.57867 & 7.64 \\
\hline $63.45(3)$ & $31(11)$ & $0.3(1)$ & 1.46488 & 28.71 \\
\hline $65.11(2)$ & $40(7)$ & $0.22(6)$ & 1.43156 & 36.95 \\
\hline $72.97(3)$ & $14(2)$ & $0.17(5)$ & 1.29546 & 13.33 \\
\hline $76.81(3)$ & $15(4)$ & $0.21(6)$ & & 13.95 \\
\hline
\end{tabular}




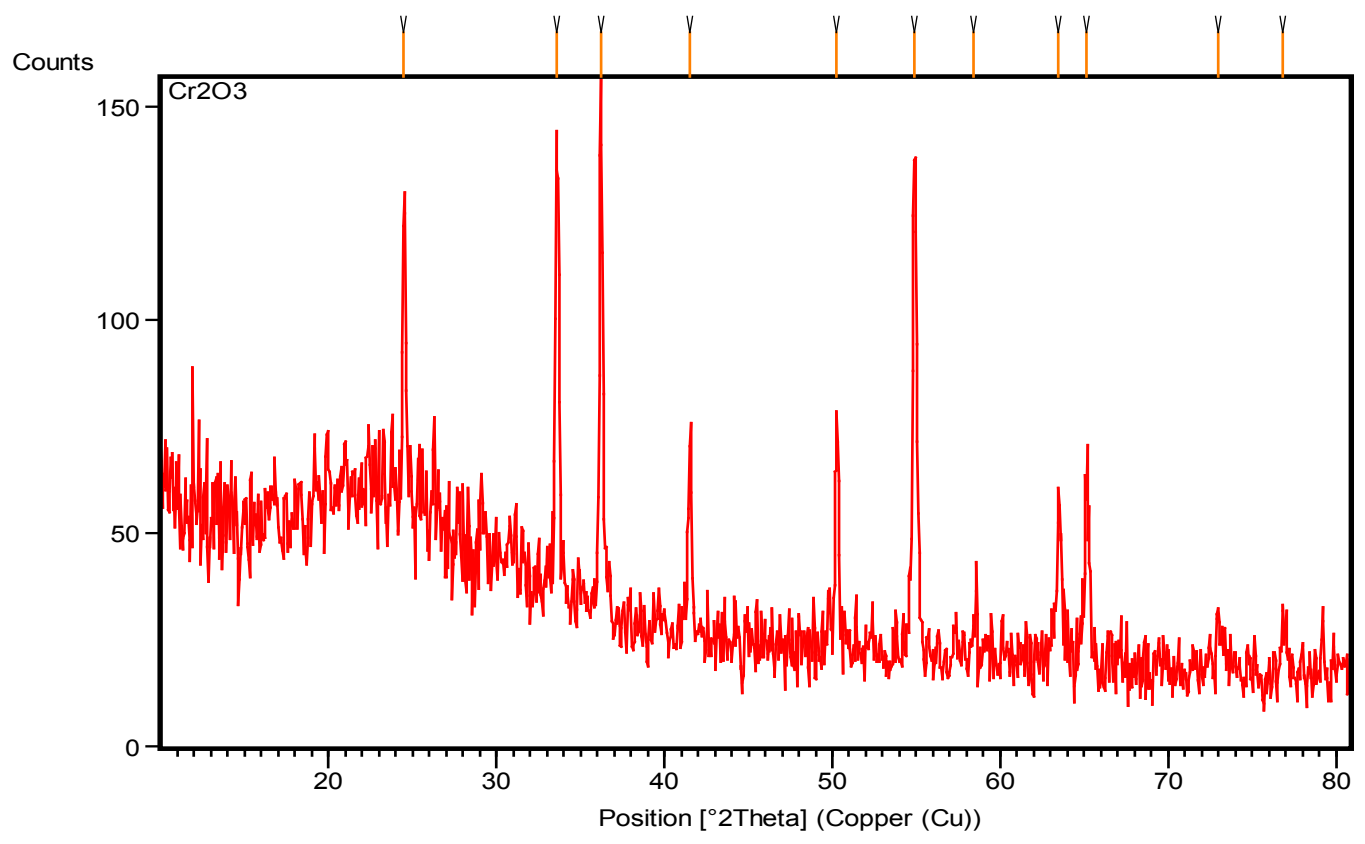

Figure 1. XRD Pattern of Pure $\mathrm{Cr}_{2} \mathrm{O}_{3}$

Table 2. Peak list with their relative intensity of XRD of $1 \% \mathrm{Al}$ doped $\mathrm{Cr}_{2} \mathrm{O}_{3}$

\begin{tabular}{|c|c|c|c|c|}
\hline Pos. [ ${ }^{\circ}$ Th.] & Height [cts] & FWHM Left [ ${ }^{2}$ Th.] & d-spacing $[\AA]$ & Rel. Int. [\%] \\
\hline 23.5116 & 58.06 & 0.1476 & 3.78391 & 99.56 \\
\hline 32.5448 & 58.12 & 0.1476 & 2.75134 & 99.66 \\
\hline 35.1311 & 55.45 & 0.1476 & 2.55449 & 95.08 \\
\hline 40.4649 & 17.73 & 0.2952 & 2.22924 & 30.40 \\
\hline 49.2204 & 21.94 & 0.2952 & 1.85124 & 37.62 \\
\hline 53.8588 & 58.31 & 0.1968 & 1.70225 & 100.00 \\
\hline 62.5259 & 24.08 & 0.2952 & 1.48552 & 41.30 \\
\hline 64.1325 & 28.97 & 0.3936 & 1.45213 & 49.69 \\
\hline 72.0428 & 9.97 & 0.7872 & 1.31092 & 17.10 \\
\hline
\end{tabular}

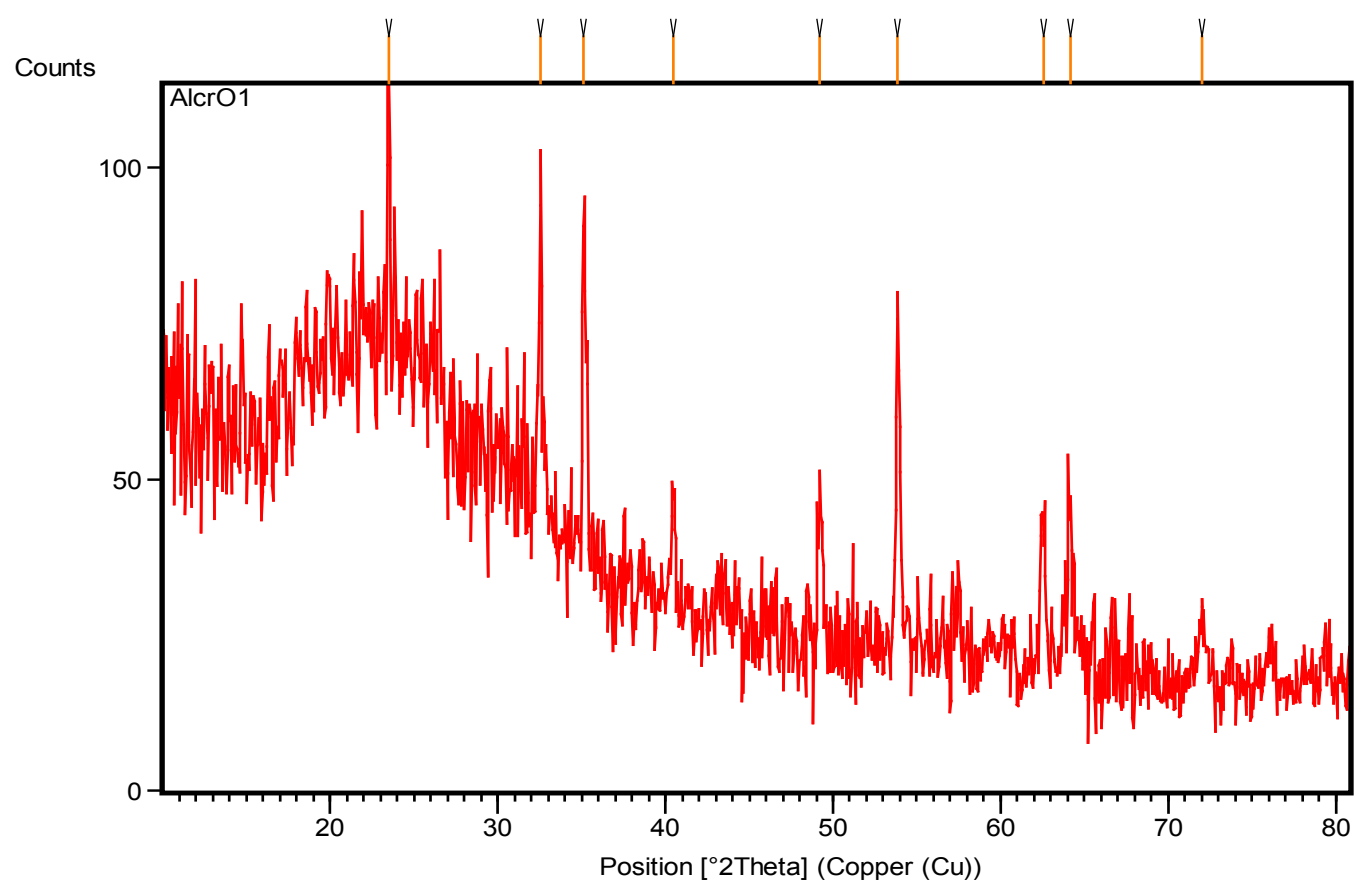

Figure 2. XRD Pattern of $1 \% \mathrm{Al}$ doped $\mathrm{Cr}_{2} \mathrm{O}_{3}$ 
Table 3. Peak list with their relative intensity of XRD of $2 \% \mathrm{Al}$ doped $\mathrm{Cr}_{2} \mathrm{O}_{3}$

\begin{tabular}{|c|c|c|c|c|}
\hline Pos. $\left[{ }^{\circ}\right.$ Th.] & Height $[\mathrm{cts}]$ & FWHM Left $\left[{ }^{\circ}\right.$ 2Th.] & d-spacing $[\AA]$ R & Rel. Int. [\%] \\
\hline 33.6057 & 35.11 & 0.3291 & 2.66687 & 85.21 \\
\hline 36.1734 & 41.20 & 0.1686 & 2.48324 & 100.00 \\
\hline 54.9401 & 24.43 & 0.3600 & 1.66990 & 59.29 \\
\hline
\end{tabular}

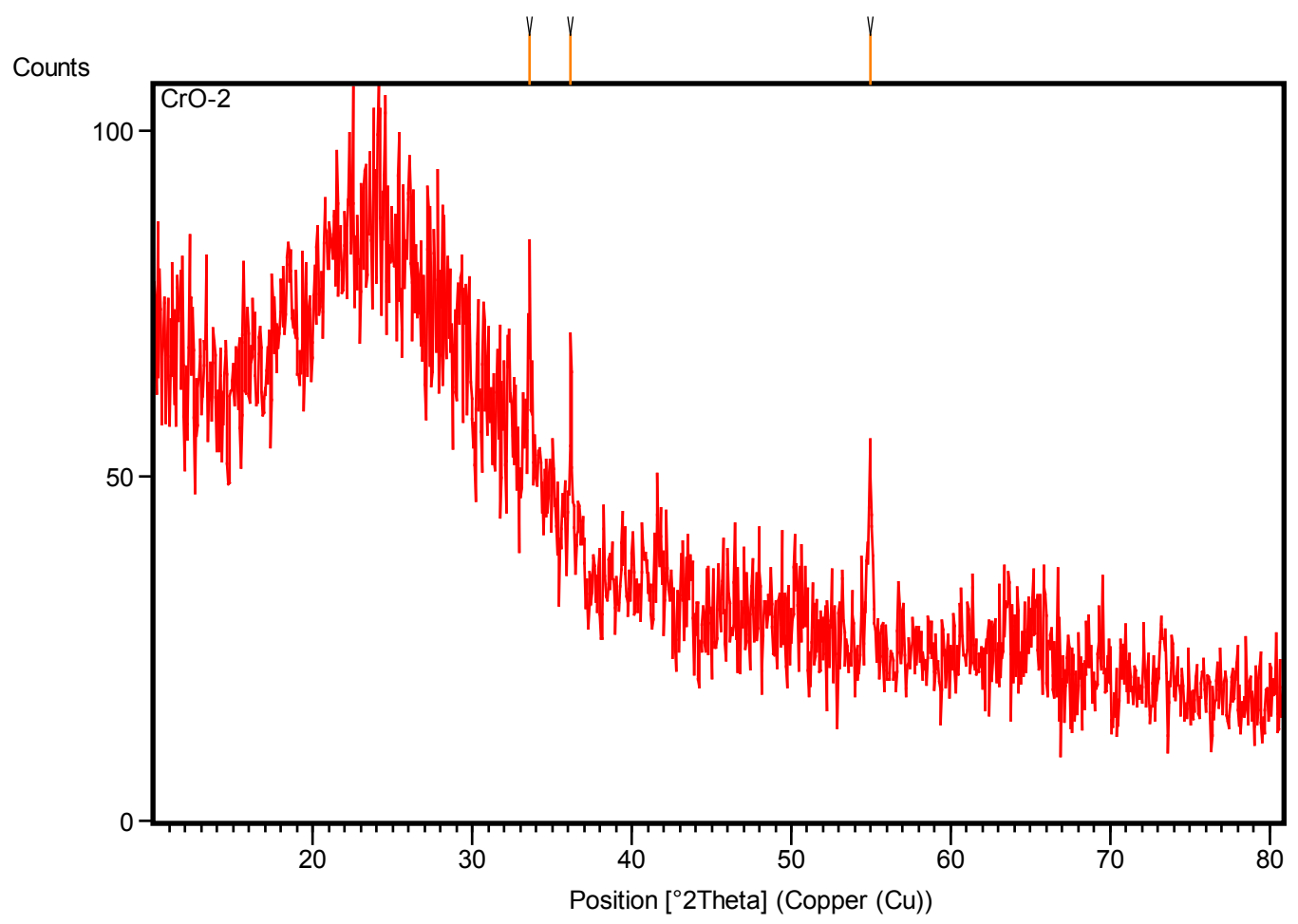

Figure 3. XRD Pattern of $2 \% \mathrm{Al}$ doped $\mathrm{Cr}_{2} \mathrm{O}_{3}$

Table 4. Peak list with their relative intensity of $\mathrm{XRD}$ of $3 \% \mathrm{Al}$ doped $\mathrm{Cr}_{2} \mathrm{O}_{3}$

\begin{tabular}{|c|c|c|c|c|}
\hline Pos. $\left[{ }^{\circ} 2 \mathrm{Th}.\right]$ & Height [cts] & FWHM Left [ $\left.{ }^{\circ} 2 \mathrm{Th}.\right]$ & d-spacing $[\AA]$ & Rel. Int. [\%] \\
\hline 23.5072 & 108.23 & 0.1968 & 3.78461 & 75.72 \\
\hline 32.5769 & 137.04 & 0.2460 & 2.74870 & 95.87 \\
\hline 35.2087 & 142.94 & 0.1968 & 2.54904 & 100.00 \\
\hline 40.5507 & 50.78 & 0.1968 & 2.22472 & 35.53 \\
\hline 49.2748 & 65.32 & 0.1476 & 1.84933 & 45.70 \\
\hline 53.8789 & 122.59 & 0.2460 & 1.70167 & 85.77 \\
\hline 62.5157 & 43.75 & 0.1968 & 1.48574 & 30.60 \\
\hline 64.1697 & 67.36 & 0.2952 & 1.45138 & 47.13 \\
\hline 72.1453 & 16.57 & 0.5904 & 1.30931 & 11.59 \\
\hline 75.8994 & 9.25 & 1.1808 & 1.25362 & 6.47 \\
\hline 78.2299 & 9.17 & 0.3936 & 1.22201 & 6.41 \\
\hline
\end{tabular}




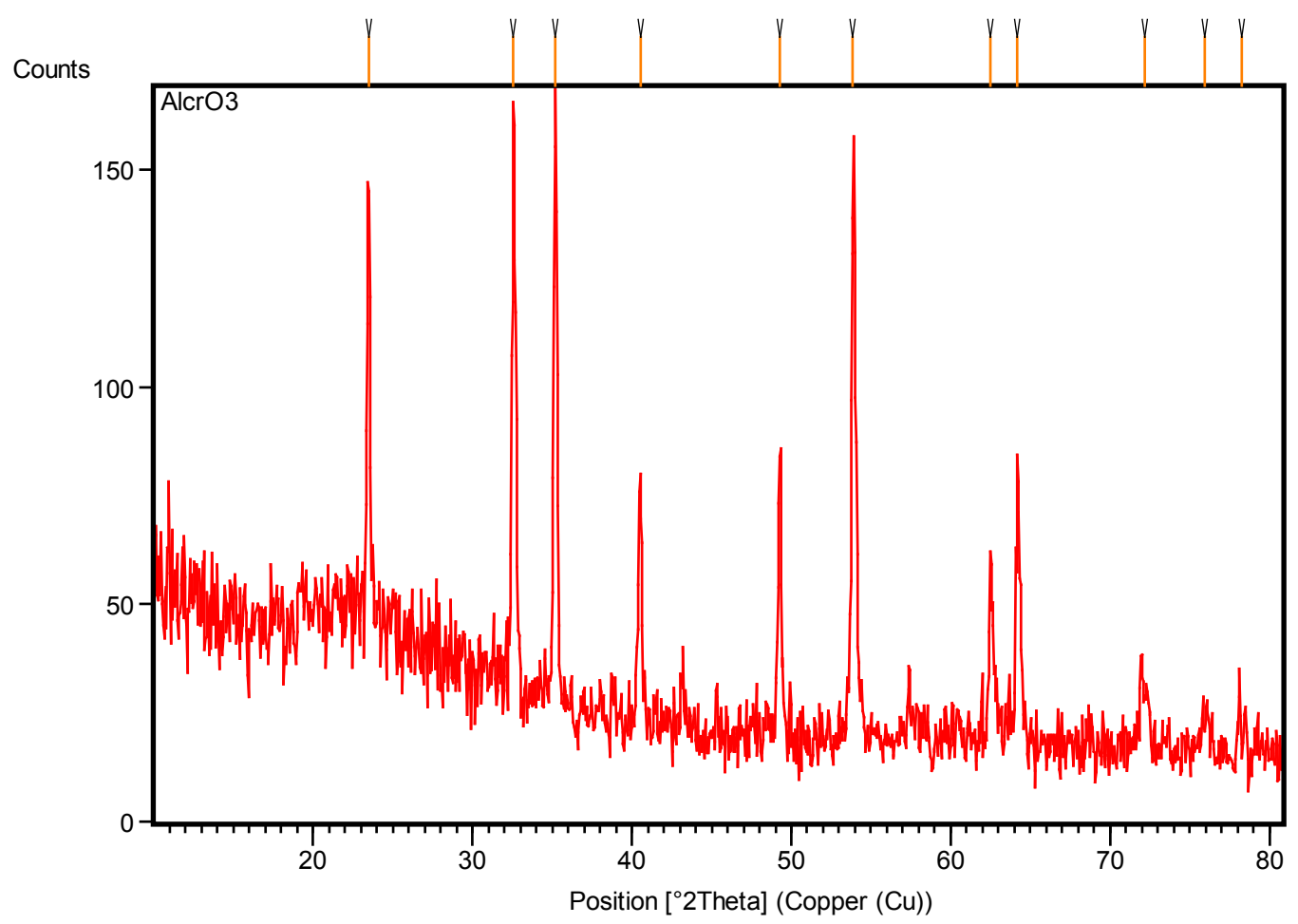

Figure 4. XRD Pattern of $3 \% \mathrm{Al}$ doped $\mathrm{Cr}_{2} \mathrm{O}_{3}$

Table 5. Peak list with their relative intensity of XRD of $5 \% \mathrm{Al}$ doped $\mathrm{Cr}_{2} \mathrm{O}_{3}$

\begin{tabular}{|c|c|c|c|c|}
\hline Pos. $\left[{ }^{\circ}\right.$ 2Th.] & Height [cts] & FWHM Left [ ${ }^{\circ}$ Th.] & d-spacing $[\AA]$ & Rel. Int. [\%] \\
\hline 23.4458 & 91.35 & 0.1968 & 3.79438 & 59.27 \\
\hline 32.5640 & 141.82 & 0.1968 & 2.74976 & 92.02 \\
\hline 35.1958 & 154.12 & 0.1968 & 2.54995 & 100.00 \\
\hline 40.4691 & 43.30 & 0.1476 & 2.22902 & 28.09 \\
\hline 49.2920 & 44.28 & 0.2952 & 1.84872 & 28.73 \\
\hline 53.8699 & 115.22 & 0.1968 & 1.70193 & 74.76 \\
\hline 62.5360 & 31.98 & 0.3936 & 1.48531 & 20.75 \\
\hline 64.2682 & 48.67 & 0.3444 & 1.44939 & 31.58 \\
\hline 72.3135 & 7.92 & 1.1808 & 1.30668 & 5.14 \\
\hline 76.1916 & 7.08 & 1.1808 & 1.24954 & 4.60 \\
\hline
\end{tabular}




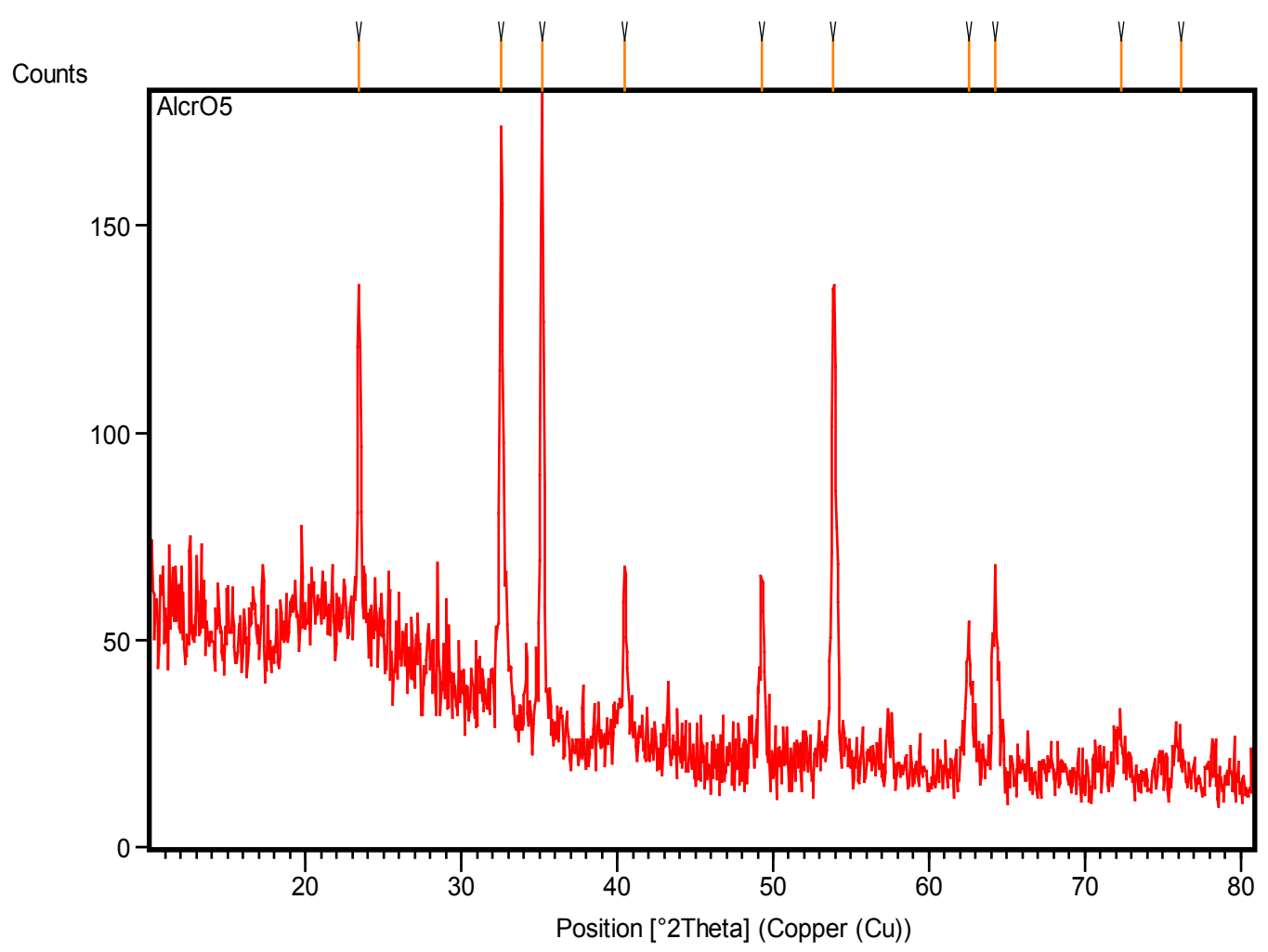

Figure 5. XRD Pattern of $5 \% \mathrm{Al}$ doped $\mathrm{Cr}_{2} \mathrm{O}_{3}$

The calculated crystalline average size of $\mathrm{Al}$ doped $\mathrm{Cr}_{2} \mathrm{O}_{3}$ naoparticles values are tabulated in Table 6 .

Table 6. Variation in crystallite size with $\mathrm{Al}$ concentration

\begin{tabular}{|c|c|c|}
\hline S.No & Concentration of Al & $\begin{array}{c}\text { Crystallite average size from } \\
\text { Scherrer formula }\end{array}$ \\
\hline 1 & $0 \%$ & 14.56 \\
\hline 2 & $1 \%$ & 13.91 \\
\hline 3 & $2 \%$ & 12.86 \\
\hline 4 & $3 \%$ & 12.16 \\
\hline 5 & $5 \%$ & 10.86 \\
\hline
\end{tabular}

From Table 6, the average size of pure $\mathrm{Cr}_{2} \mathrm{O}_{3}$ is observed as $14.56 \mathrm{~nm}$ which decreases to $10.86 \mathrm{~nm}$ as the concentration of $\mathrm{Al}$ increases form $1 \%$ to $5 \%$. This decrease in average size of nanoparticles with increase of $\mathrm{Al}$ concentration due to the increase in the densities of nucleation centers and thus to grow resulting in small crystallites

\section{SEM and EDAX Studies}

Scanning Electron Microscopy and Energy dispersive
X-ray analysis (EDAX) studies were carried out. Scanning Electron micrographs were obtained using a VEGA3 TESCAN Instrument. Energy dispersive X-ray analysis (EDAX) was used to estimate the composition of the materials using a Bruker CAL 4231 Model attached with Energy Dispersive Spectrometer of EDAX inc. USA.

SEM images of pure $\mathrm{Cr}_{2} \mathrm{O}_{3}$ and $1 \%, 2 \%, 3 \%, 5 \% \mathrm{Al}$ doped $\mathrm{Cr}_{2} \mathrm{O}_{3}$ are shown in figures 6-10. These micrographs exhibited the formation of nanoparticles of $\mathrm{Cr}_{2} \mathrm{O}_{3}$ and $\mathrm{Al}$ doped $\mathrm{Cr}_{2} \mathrm{O}_{3}$. From the images it can be considered the particles of $\mathrm{Al}$ doped are smaller in size as compared to pure $\mathrm{Cr}_{2} \mathrm{O}_{3}$ and the images are well distinguishable also verifies the difference in from Scherrer formula's result in Table 6. To check the chemical composition of the material, an energy dispersive X-ray (EDS) spectroscopy analysis was performed. Figure 11 shows the EDS spectra of $2 \% \mathrm{Al}$ doped $\mathrm{Cr}_{2} \mathrm{O}_{3}$ nanoparticles which confirm the synthesis of $\mathrm{Al}$ doped $\mathrm{Cr}_{2} \mathrm{O}_{3}$ nanoparticles. The surface of the $\mathrm{Cr}_{2} \mathrm{O}_{3}$ and $\mathrm{Al}$ doped nanoparticles also exhibited elements of $\mathrm{O}, \mathrm{Cr}$ and $\mathrm{Al}$. Here the aluminium is present in elemental form. These results are consistent with the XRD data. 


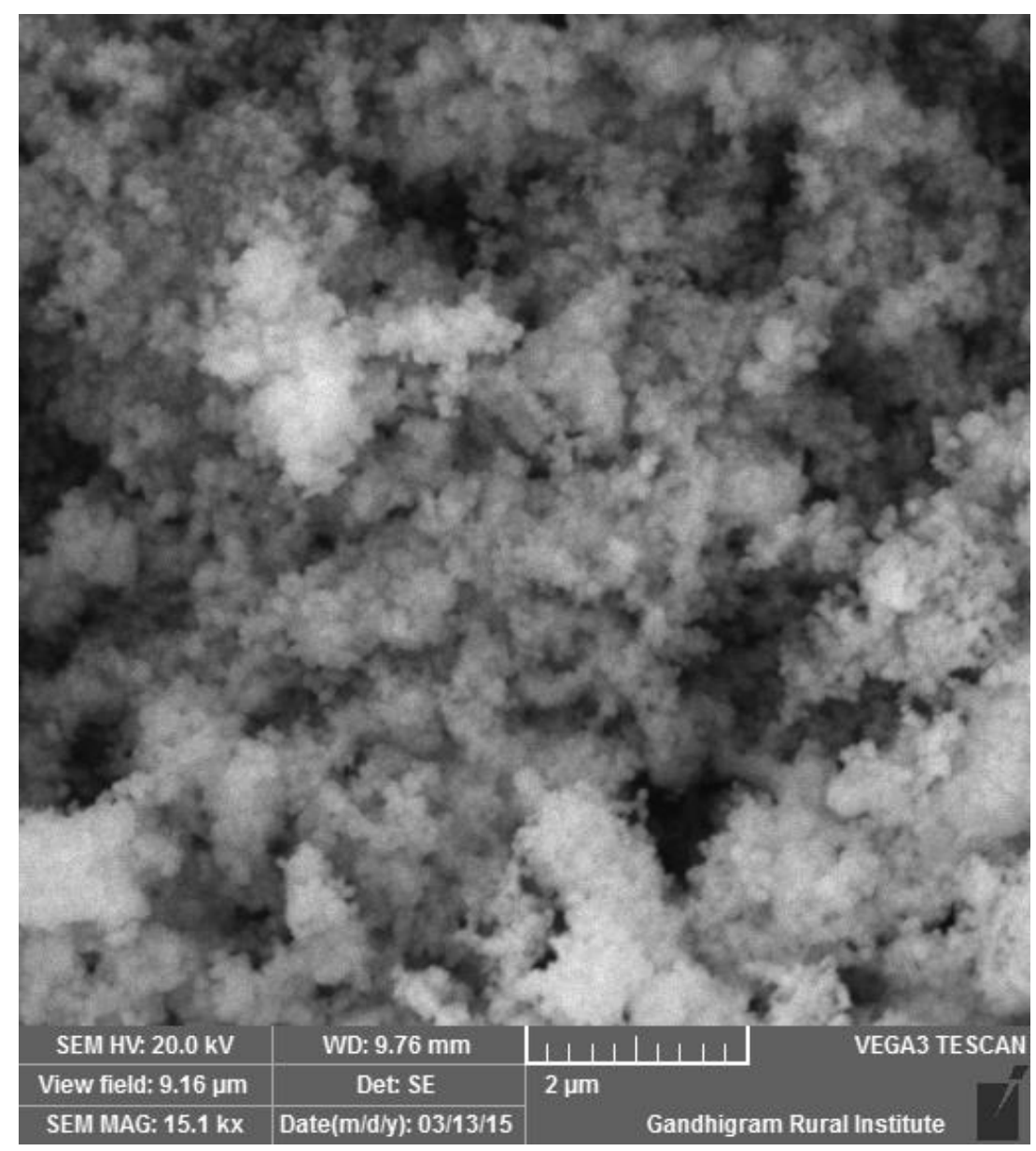

Figure 6. SEM image of Pure $\mathrm{Cr}_{2} \mathrm{O}_{3}$

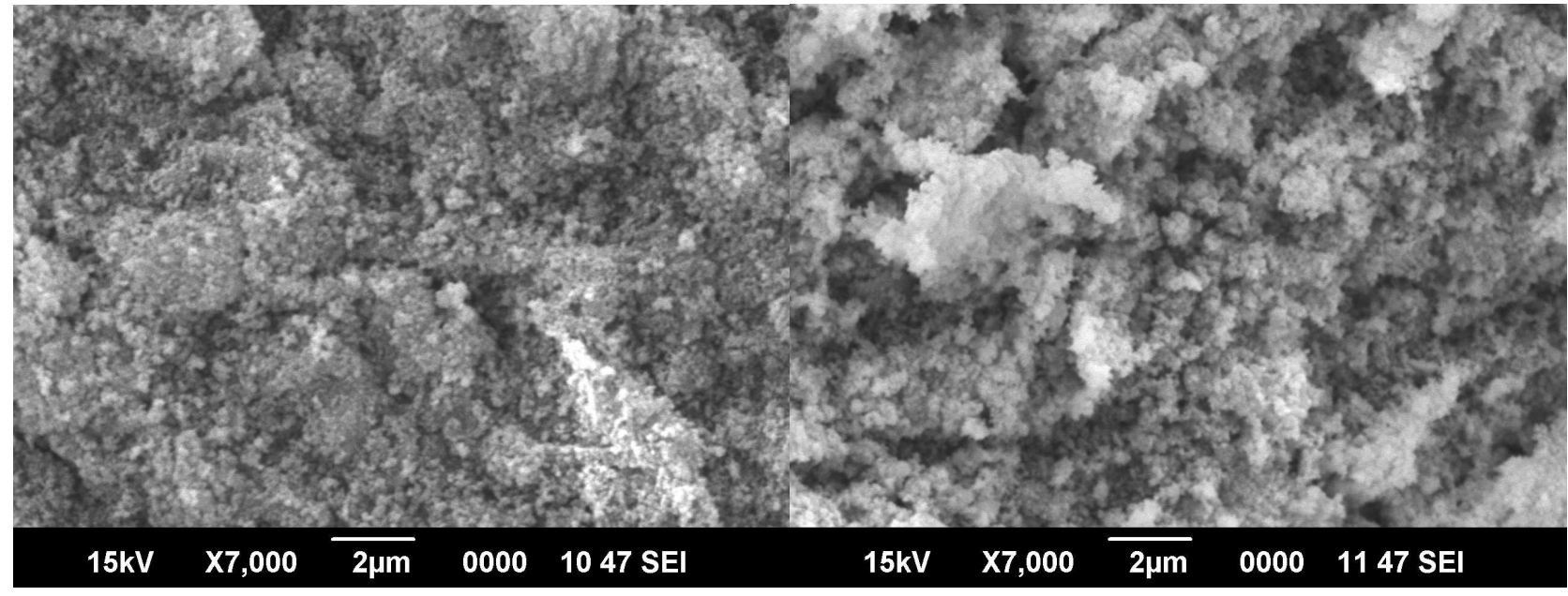

Figure 7. $\mathrm{SEM}$ image of $1 \% \mathrm{Al}$ doped $\mathrm{Cr}_{2} \mathrm{O}_{3}$

Figure 8. SEM image of $2 \% \mathrm{Al}$ doped $\mathrm{Cr}_{2} \mathrm{O}_{3}$ 


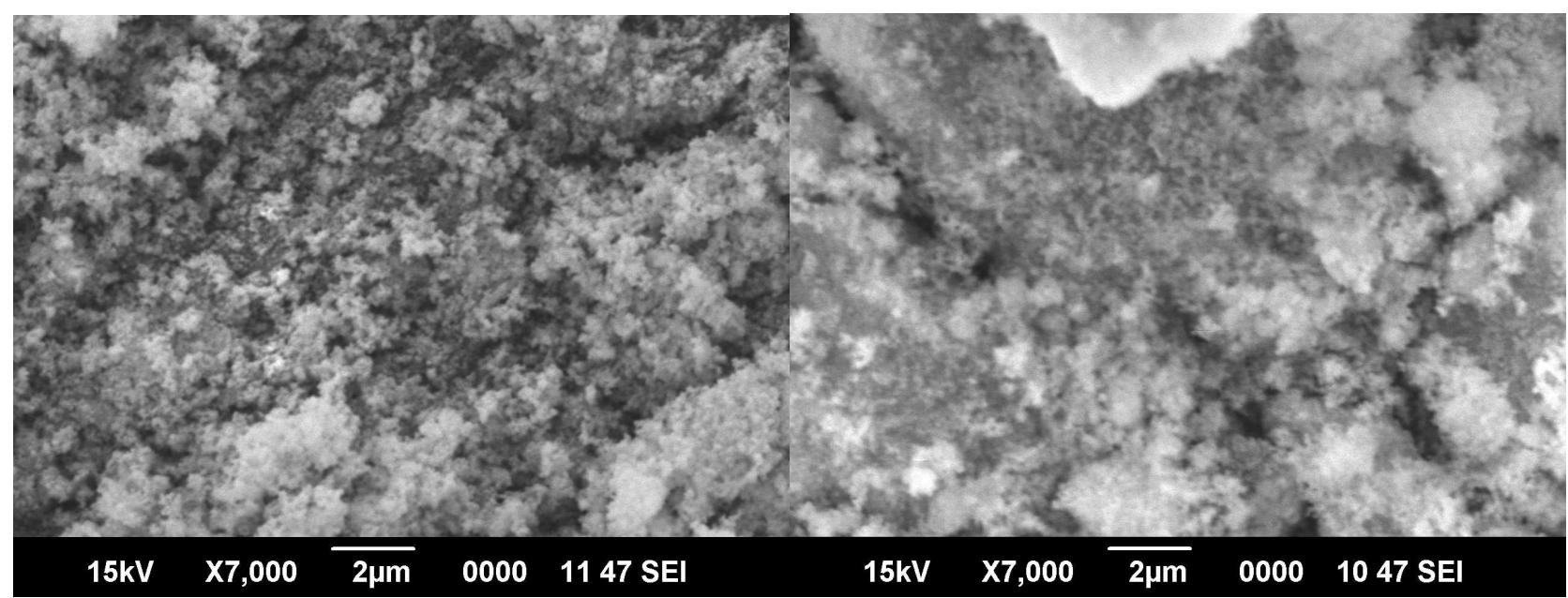

Figure 9. SEM image of $5 \% \mathrm{Al}$ doped $\mathrm{Cr}_{2} \mathrm{O}_{3}$

Figure 10. $\mathrm{SEM}$ image of $5 \% \mathrm{Al}$ doped $\mathrm{Cr}_{2} \mathrm{O}_{3}$

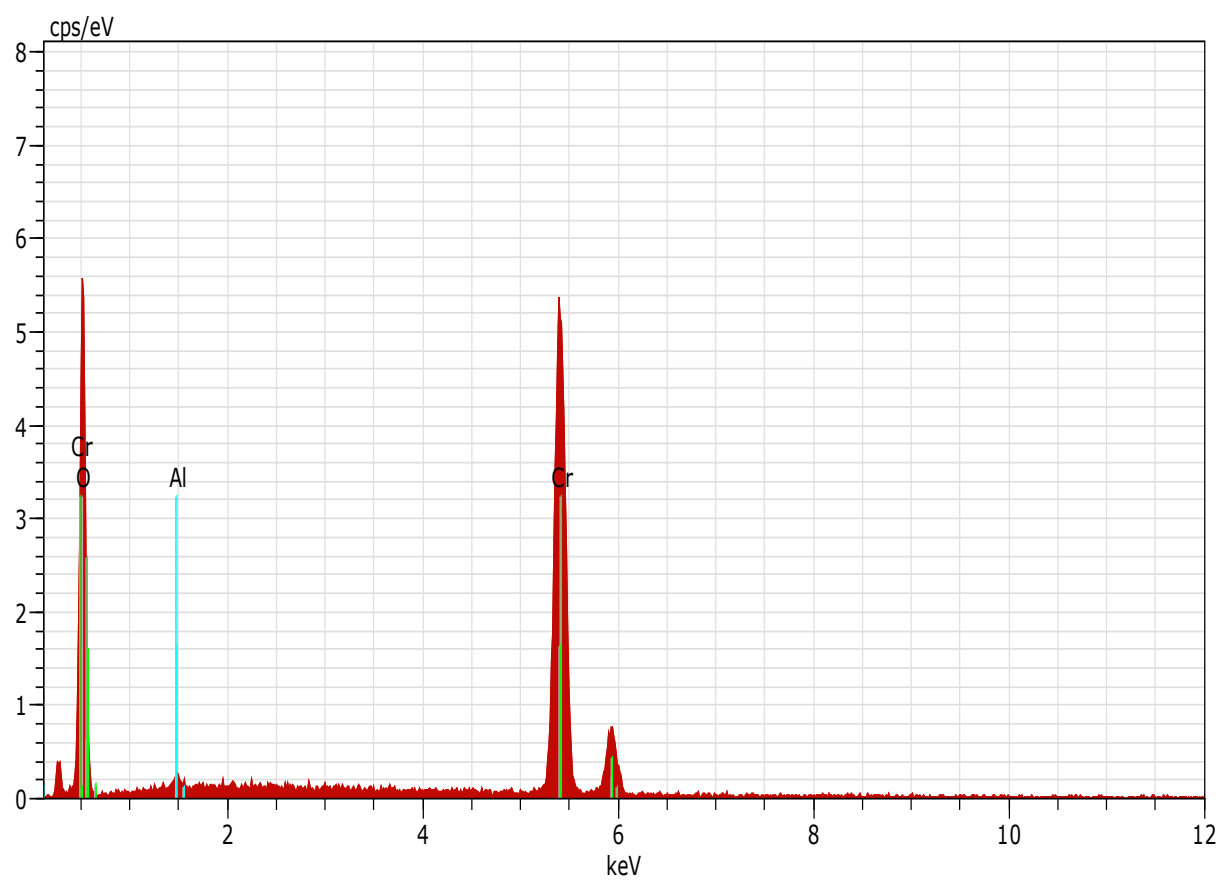

Figure 11. EDAX image of $2 \% \mathrm{Al}$ doped $\mathrm{Cr}_{2} \mathrm{O}_{3}$

\section{Fourier Transform Infrared Spectroscopy Analysis}

The FTIR spectra were recorded in Perkin Elmer 100 spectrophotometer based in Najran University Saudi Arabia. The composition and quality of the material was investigated by the FTIR spectroscopy. The FTIR spectra of pure $\mathrm{Cr}_{2} \mathrm{O}_{3}$ nanoparticles are shown in Figure 12. The spectra shows the $\mathrm{Cr}-\mathrm{O}$ bond appear at around $450-490 \mathrm{~cm}^{-1}$. The band at around $490 \mathrm{~cm}^{-1}$ may be related with oxygen vacancy or oxygen deficiency in $\mathrm{Cr}_{2} \mathrm{O}_{3}$. This oxygen deficiency should translate into an enhanced green emission in UV absorption spectra.

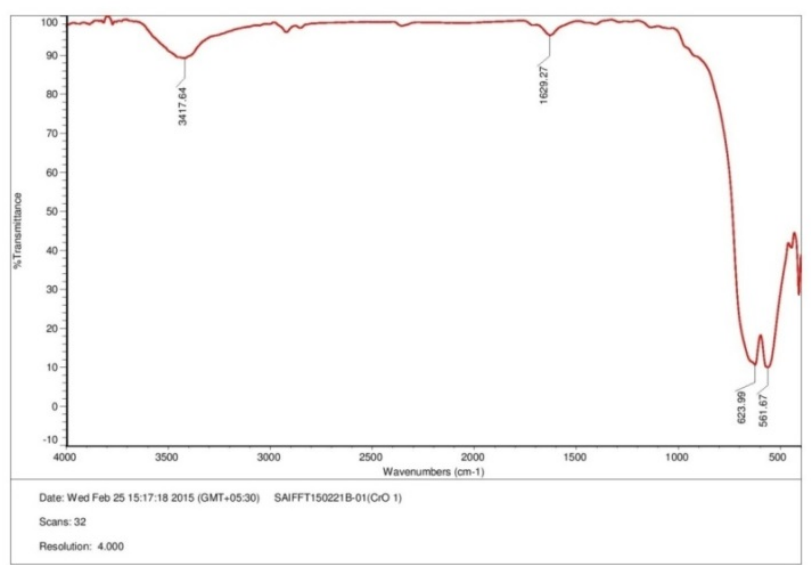

Figure 12. FTIR Spectrum of pure $\mathrm{Cr}_{2} \mathrm{O}_{3}$ nanoparticles 


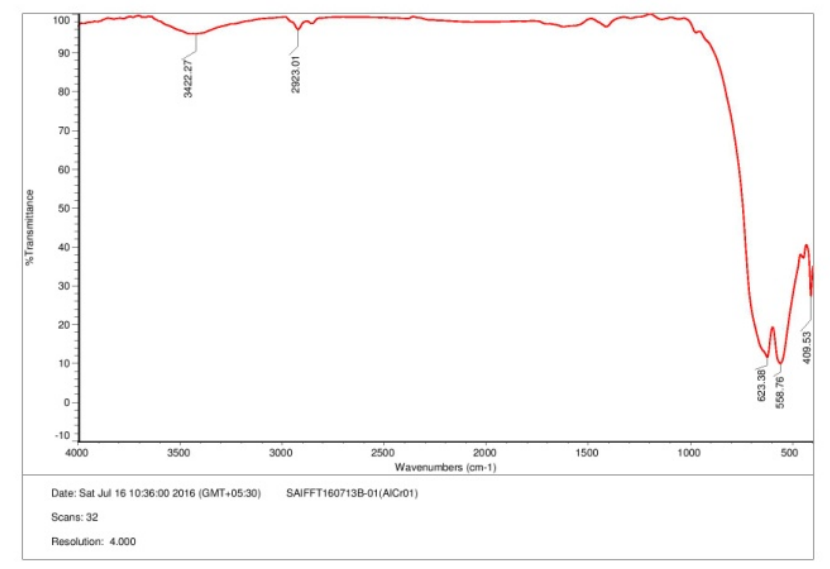

Figure 13. FTIR Spectrum of $1 \% \mathrm{Al}$ doped $\mathrm{Cr}_{2} \mathrm{O}_{3}$ nanoparticles

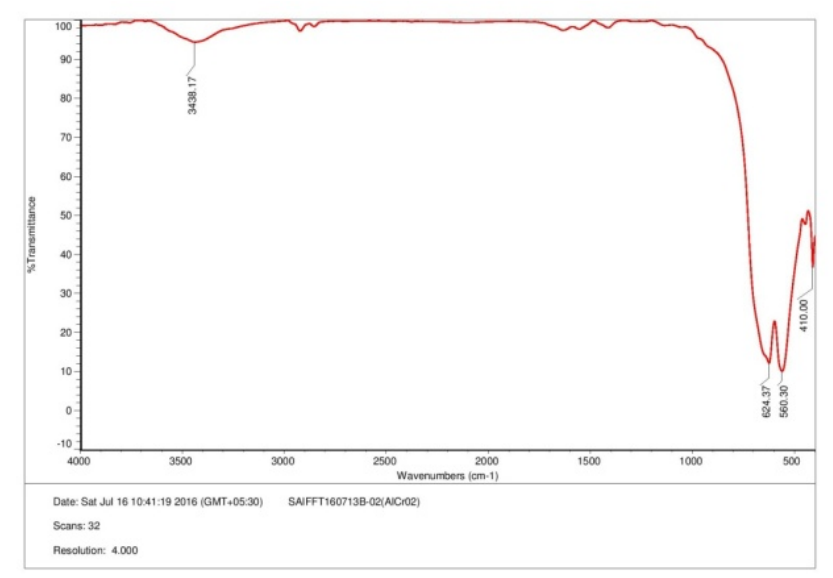

Figure 14. FTIR Spectrum of $2 \% \mathrm{Al}$ doped $\mathrm{Cr}_{2} \mathrm{O}_{3}$ nanoparticles

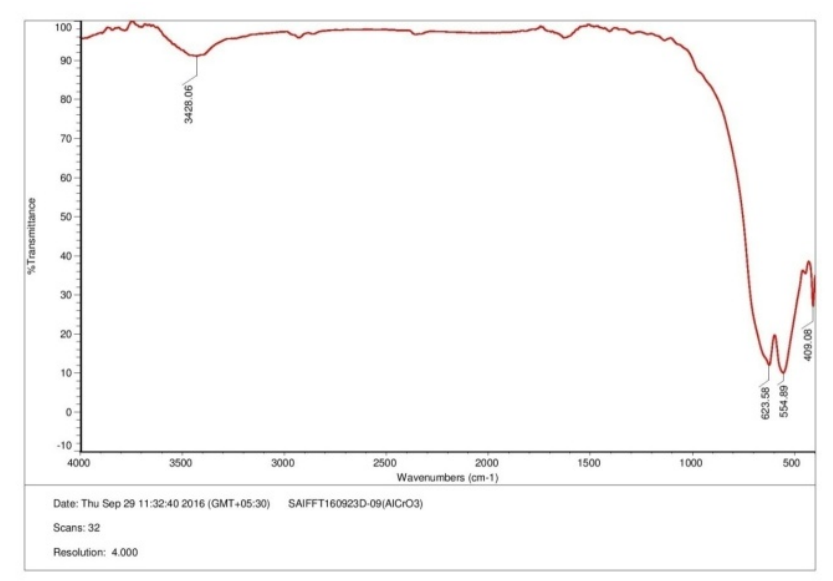

Figure 15. FTIR Spectrum of $3 \% \mathrm{Al}$ doped $\mathrm{Cr}_{2} \mathrm{O}_{3}$ nanoparticles

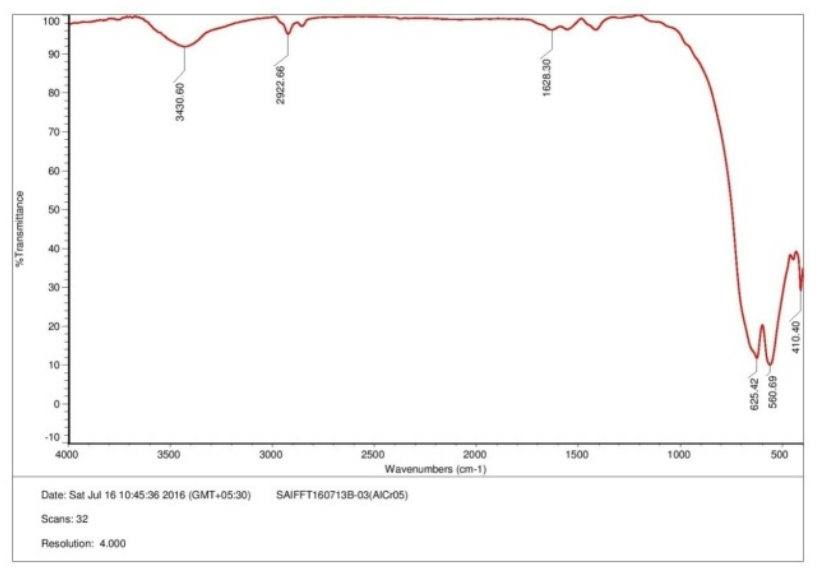

Figure 16. FTIR Spectrum of $5 \% \mathrm{Al}$ doped $\mathrm{Cr}_{2} \mathrm{O}_{3}$ nanoparticles

The peaks at $1350 \mathrm{~cm}^{-1}$ correspond to the $\mathrm{C}-\mathrm{O}$ absorption of $\mathrm{Cr}_{2} \mathrm{O}_{3}$ surface. The weak absorption band at $2367 \mathrm{~cm}^{-1}$ stands for carbonate that probably comes from the atmospheric carbon dioxide during synthesis. The broad peaks around $3429 \mathrm{~cm}^{-1}$ is assigned to the O-H stretching mode of hydroxyl group and $1634 \mathrm{~cm}^{-1}$ (bending) are due to asymmetrical stretching of the chromium carboxylate. The FTIR spectra of $1 \% \mathrm{Al}, 2 \%, 3 \%, 5 \%$ aluminium doped $\mathrm{Cr}_{2} \mathrm{O}_{3}$ nanoparticles in different concentration of $\mathrm{Al}$ are shown in Figures 13-16. In FTIR studies it is found that there are no significant changes as the concentration of $\mathrm{Al}$ increases.

\section{UV-Visible Absorption Spectroscopy Studies}

The spectrum of absorption versus wavelength was recorded in Shimadzu UV Spectrophotometer. The optical absorption spectra of pure $\mathrm{Cr}_{2} \mathrm{O}_{3}$ and $1 \%, 2 \%, 3 \%$ and $5 \% \mathrm{Al}$ doped $\mathrm{Cr}_{2} \mathrm{O}_{3}$ as the function of wavelength ranging from 0 to $1500 \mathrm{~nm}$ are shown in figures 17-21.

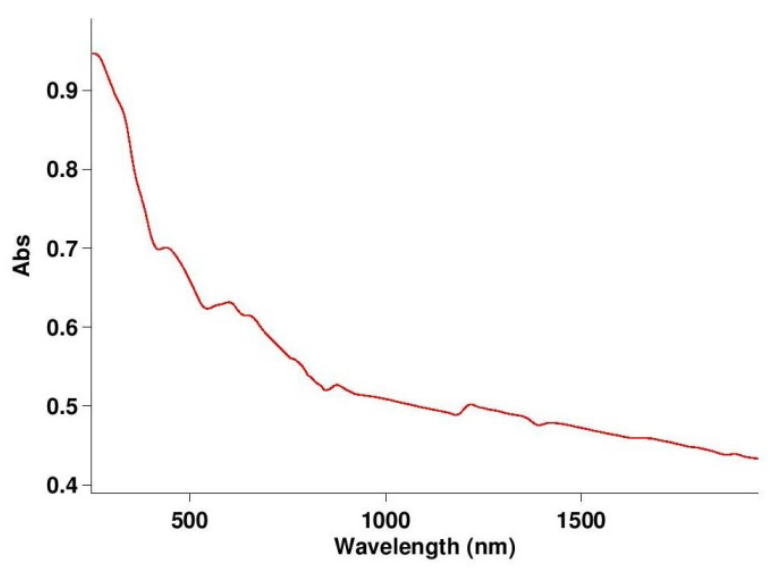

Figure 17. UV-Vis Spectrum of pure $\mathrm{Cr}_{2} \mathrm{O}_{3}$ nanoparticles 
For pure $\mathrm{Cr}_{2} \mathrm{O}_{3}$ nano particles, the absorption intensity decreases sharply and suddenly for wavelength at $248 \mathrm{~nm}$. This was assigned to the intrinsic band gap of the $\mathrm{Cr}_{2} \mathrm{O}_{3}$ due to electron transitions from the valence band to the conduction band. Then the absorption intensity decreases slowly as the wavelength increases. After being doped with $\mathrm{Al}$, the absorption peaks shifted towards longer wavelength at $277 \mathrm{~nm}$ i.e. red shifted. With doping of aluminium, the absorption spectra shows broadness after the UV peak which might be caused by the surface related defects in the nano particles. The UV emission band is probably due to the radiative recombination of excitons in the surfaces of $\mathrm{Cr}_{2} \mathrm{O}_{3}$ particles and the visible emission band results from the transition associated with the deep levels due to the oxygen vacancy.

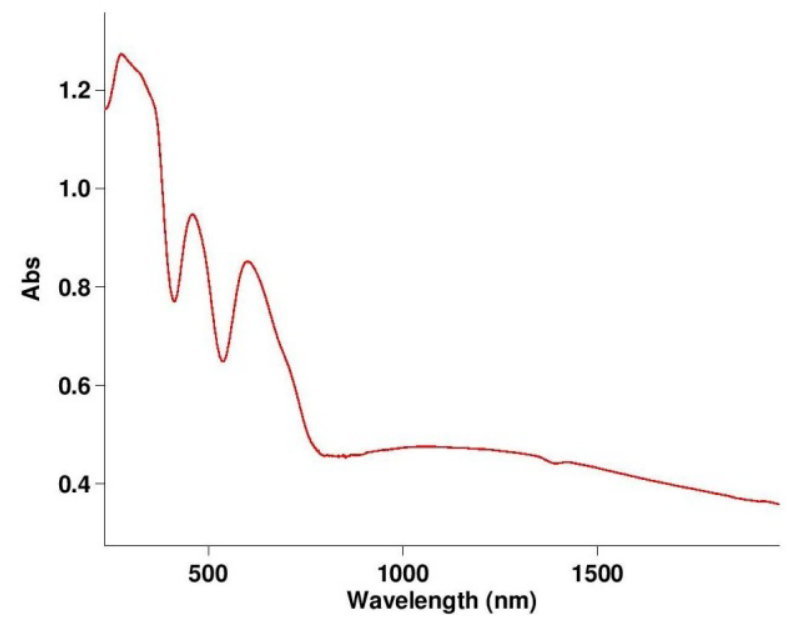

Figure 18. UV-Vis Spectrum of $1 \% \mathrm{Al}$ doped $\mathrm{Cr}_{2} \mathrm{O}_{3}$ nanoparticles

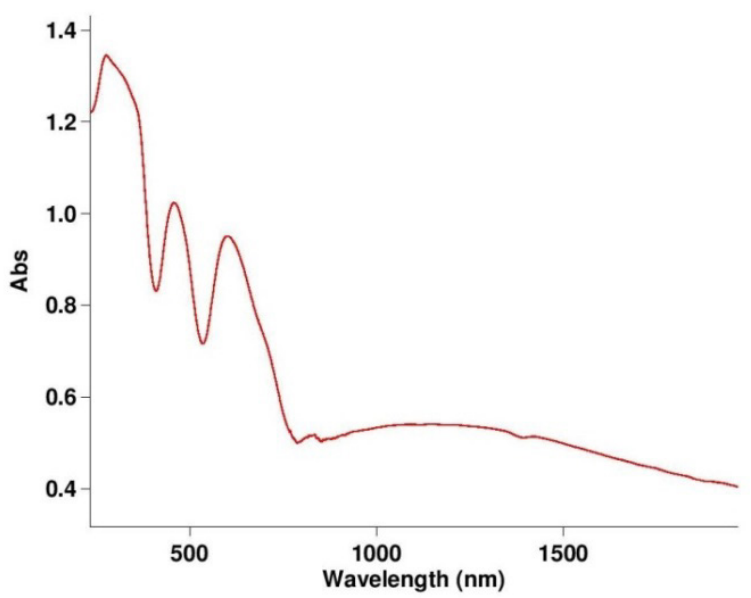

Figure 19. UV-Vis Spectrum of $2 \% \mathrm{Al}$ doped $\mathrm{Cr}_{2} \mathrm{O}_{3}$ nanoparticles

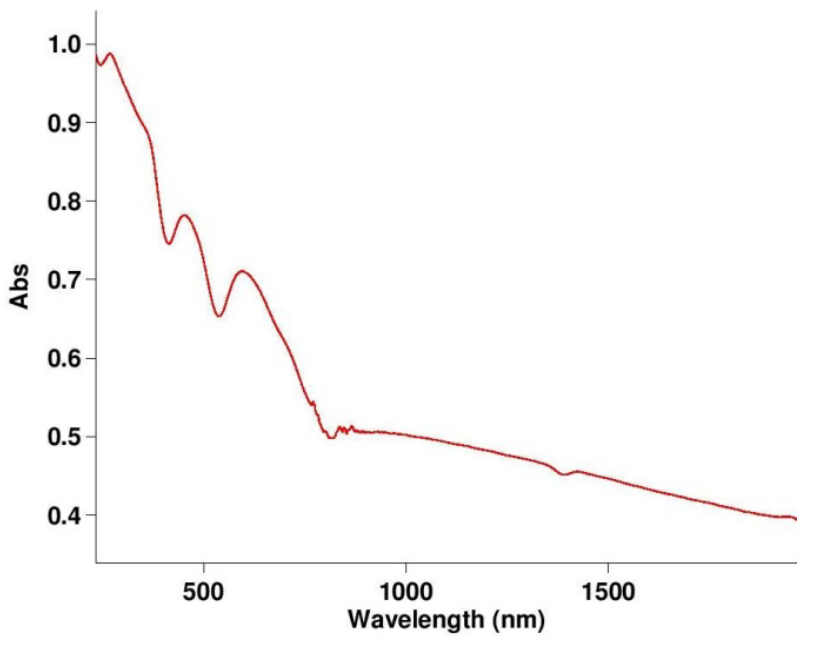

Figure 20. UV-Vis Spectrum of $3 \% \mathrm{Al}$ doped $\mathrm{Cr}_{2} \mathrm{O}_{3}$ nanoparticles

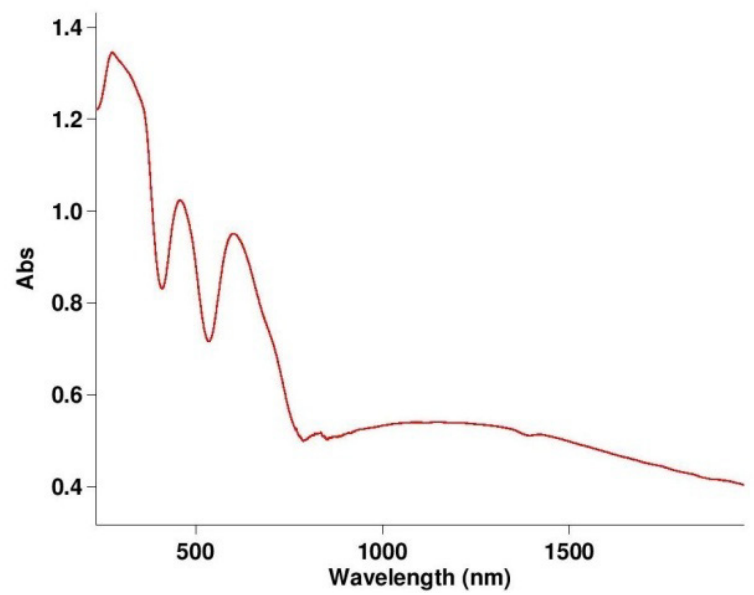

Figure 21. UV-Vis Spectrum of $5 \% \mathrm{Al}$ doped $\mathrm{Cr}_{2} \mathrm{O}_{3}$ nanoparticles

\section{Band Gap Determination}

The optical band gap of the nanopowders was determined by applying the Tauc relation as given below $\alpha \mathrm{h} v=\mathrm{B}(\mathrm{h} v-$ Eg $) n$, where $\alpha$ is the absorption coefficient[AC] $(\alpha=$ $2.303 \mathrm{~A} / \mathrm{t}$, here $\mathrm{A}$ is the absorbance and $\mathrm{t}$ is the thickness of the cuvett), $\mathrm{B}$ is a constant, $\mathrm{h}$ is Planck's constant, $v$ is the photon frequency, and Eg is the optical band gap. The value of $n=1 / 2,3 / 2,2$ or 3 depending on the nature of the electronic transition responsible for absorption and $n=1 / 2$ for direct band gap semiconductor. An extrapolation of the linear region of a plot of $(\alpha \mathrm{hv})^{2}$ on the Y-axis and photon energy (hv) on the $\mathrm{X}$-axis (Tauc Plot) gives the value of the optical band gap (Eg) as shown in Figures 22-26. The band gap values found from the Tauc plots are shown in table 7 for all samples. 
Table 7. Variation in optical band gap with $\mathrm{Al}$ concentration

\begin{tabular}{|c|c|c|}
\hline S.No & Al Concentration & Optical band gap (eV) \\
\hline 1 & $0 \%$ & 3.48 \\
\hline 2 & $1 \%$ & 2.12 \\
\hline 3 & $2 \%$ & 2.10 \\
\hline 4 & $3 \%$ & 1.95 \\
\hline 5 & $5 \%$ & 1.90 \\
\hline
\end{tabular}

From the table 7, the optical band gap for the undoped $\mathrm{Cr}_{2} \mathrm{O}_{3}$ is observed as $3.48 \mathrm{eV}$. On doping with different concentrations from $1 \%$ to $5 \%$ of $\mathrm{Al}$, Eg value decreases from $3.48 \mathrm{eV}$ to $2.12 \mathrm{eV}$.

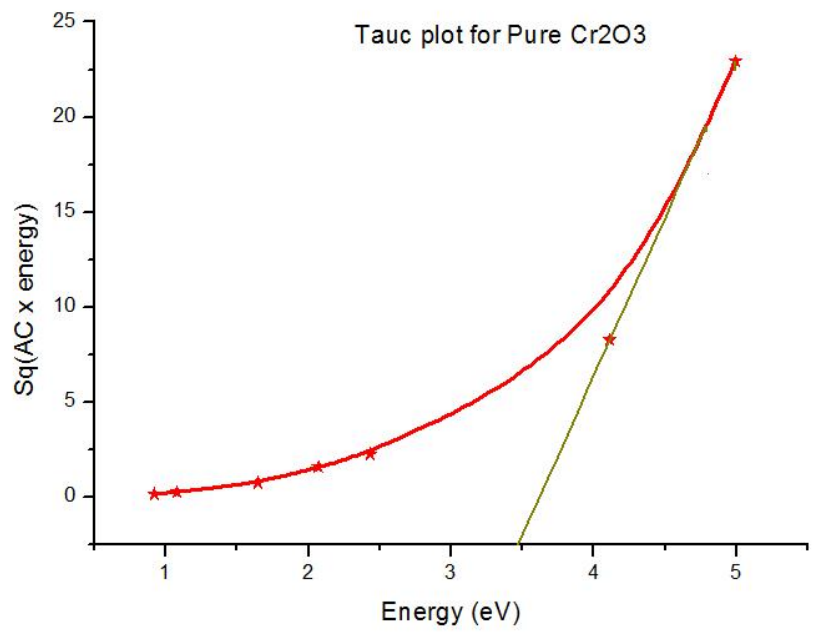

Figure 22. Plot of $(\alpha h v)^{2}$ vs photon energy (hv) for undoped $\mathrm{Cr}_{2} \mathrm{O}_{3}$

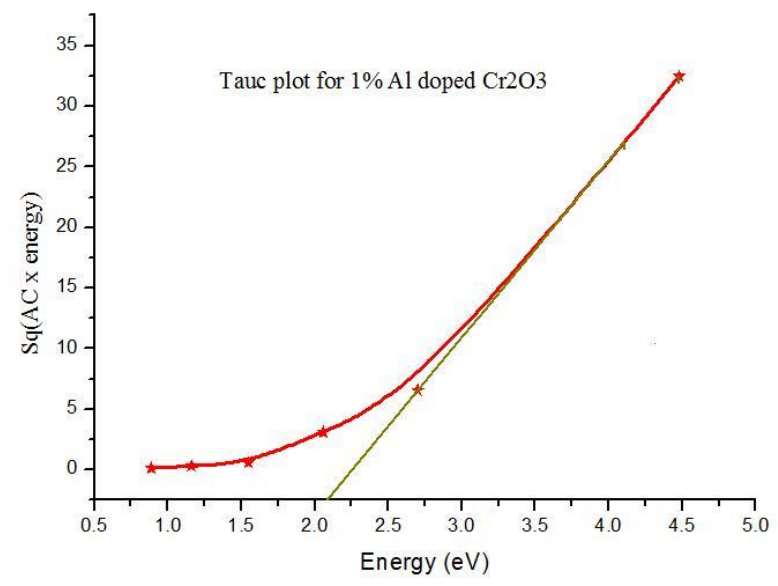

Figure 23. Plot of $(\alpha h v)^{2}$ vs photon energy (hv) for $1 \% \mathrm{Al}$ doped $\mathrm{Cr}_{2} \mathrm{O}_{3}$

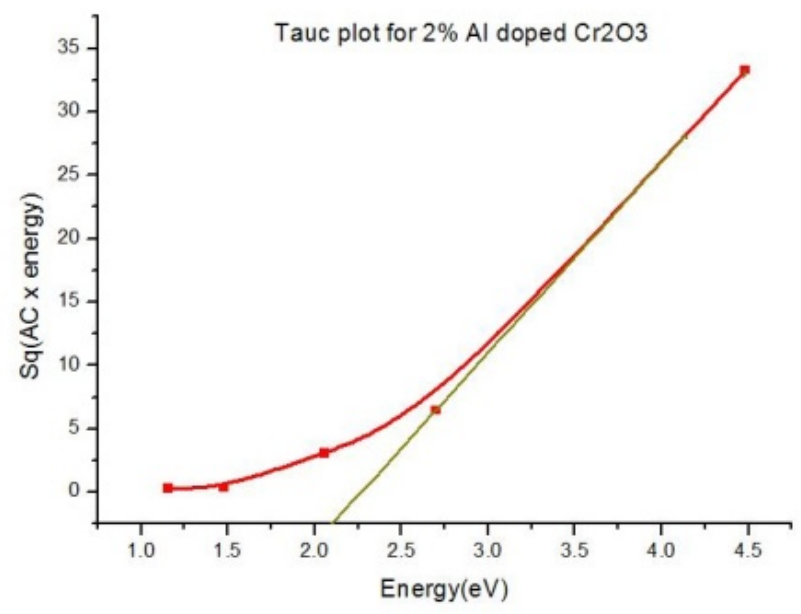

Figure 24. Plot of $(\alpha h v)^{2}$ vs photon energy (hv) for $2 \% \mathrm{Al}$ doped $\mathrm{Cr}_{2} \mathrm{O}_{3}$

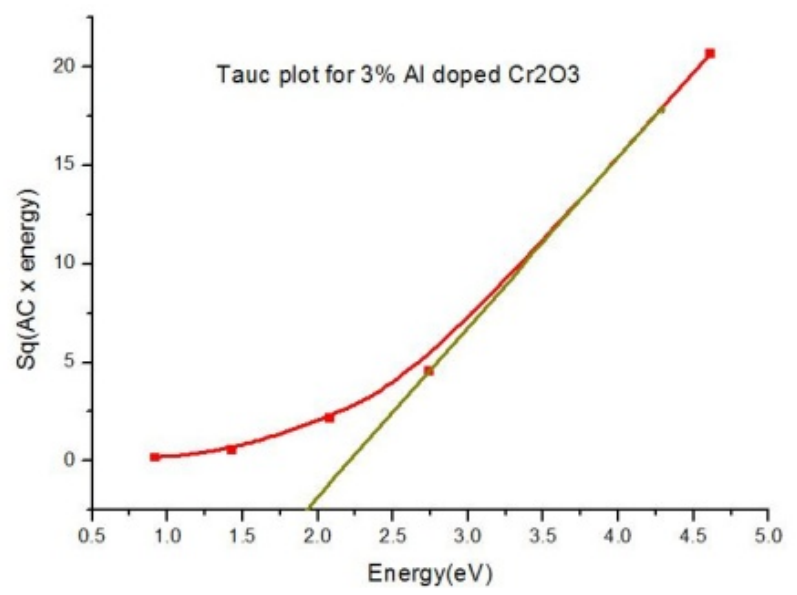

Figure 25. Plot of $(\alpha h v)^{2}$ vs photon energy (hv) for $3 \% \mathrm{Al}$ doped $\mathrm{Cr}_{2} \mathrm{O}_{3}$

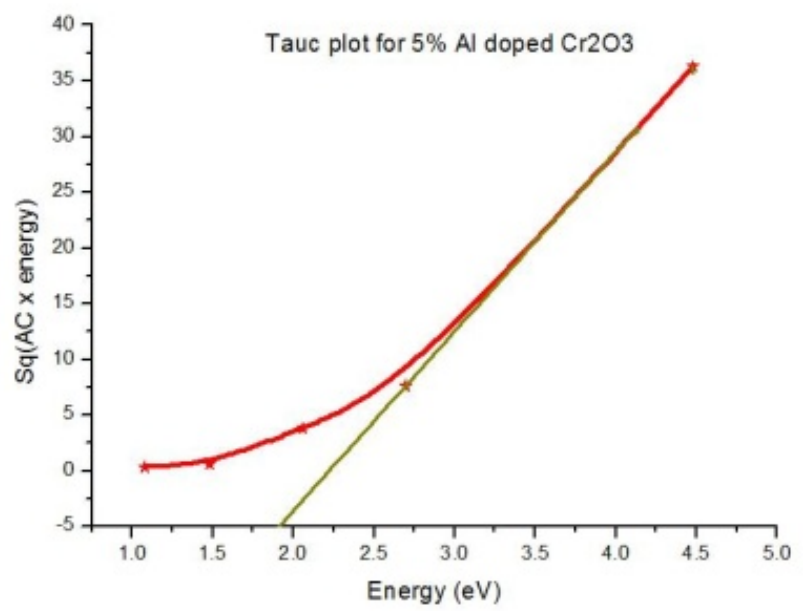

Figure 26. Plot of $(\alpha h v)^{2}$ vs photon energy (hv) for $2 \% \mathrm{Al}$ doped $\mathrm{Cr}_{2} \mathrm{O}_{3}$ 


\section{Conclusions}

In this paper, we have described the synthesis, structural, morphological and optical characterization of a series of $\mathrm{Al}$ doped $\mathrm{Cr}_{2} \mathrm{O}_{3}$ nanoparticles by simple cost effective solvothermal microwave irradiation technique. Aluminium doped $\mathrm{Cr}_{2} \mathrm{O}_{3}$ nano particles were prepared by using chromium nitrate and triethanolamine as template and aluminium nitrate in different concentrations $(1 \%, 2 \%, 3 \%$, $5 \%$ ) as the source for aluminium dopant. Regarding the structural properties, a systematic decrease in the unit cell volume, crystallite size, and changes in the FWHM parameter were observed in concurrence with the presence of Al dopant in the prepared nanoparticles. The best results were obtained. The structure and phase of the as prepared materials were determined by using the XRD. The average size of the particles was measured by Scherer formula for both doped and pure $\mathrm{Cr}_{2} \mathrm{O}_{3}$. The morphology and structural analysis was done by the SEM. Further the presence of aluminium dopants was confirmed EDAX. And prepared nano particles were also analyzed for FTIR, UV-Visible spectroscopic techniques. The optical band values (Eg) values were further obtained from Tauc plots.

\section{REFERENCES}

[1] C.N.R. Rao, A. Muller, A.K. Cheetham, "The Chemistry of Nanomaterials; Synthesis, Properties and Applications". Wilky, Weinheim 2004.

[2] A.K. Bandyopadhyay, "Nano Materials: In Architecture, Interior Architecture and Design New Age International", New Delhi 2008.

[3] T. Pradeep, "Nano: The Essentials, understanding Nanoscience and nanotechnology", Tata Mc-Graw-Hill Publishing company Limited, New Delhi 2007.

[4] Bihari B., Eilers, H., Tissue, B. M. "Spectra and dynamics of monoclinic $\mathrm{Eu}_{2} \mathrm{O}_{3}$ and $\mathrm{Eu}^{3+}: \mathrm{Y}_{2} \mathrm{O}_{3}$ nanocrystals." Journal of Luminescence 1997, 75, 1-10.

[5] Fernandez - Garcia, M. Martinez - Arias, A. Hanson J.C. and Rodriguez, J.A. "Nanostructured oxides in Chemistry. Characteristics and properties." Chem. Rev.2004, 104: 4063 4104.

[6] S.Y. Bae, H.W. Seo and J.H Park, "Single-crystalline AlZnO nanowires/nanotubes synthesized at low temperature." J. Phy. Chem. B. 2004, 108, 5206-5214.

[7] Y.J. Chem, J.B. Li et al., "The effect of vapor concentration on the formation of nanowires" .J. Cryst Growth.2002, 245, 163-174.

[8] J.M. Wu, H.C. Shih, W.T. Wn, Y.K. Tseng and I.C Chen. "The Characteristics of low-temperature-synthesized $\mathrm{ZnS}$ and $\mathrm{ZnO}$ nanoparticles" J. Cryst. Growth2005, 281, 384-391.

[9] Tsoncheva, T. Roggenbuck, J. Paneva, D. Dimitrov, M. Mitov, I. and Froba M. "Nanosized Iron and Chromium oxides supported on mesoporous $\mathrm{CeO}_{2}$ and SBA-15 silica. Physico chemical and catalytic study." Apply surf. Sci.2010, 257, 523 530 .
[10] P.M.T. Cavalcante, M. Dondi, G. Guarini, M. Raimondo, G. Baldi, "Colour performance of ceramic nano-pigments." Dyes pigments, 2009, 80, 226-232.

[11] Rao. T.V.M. Yang, Y. and Sayari A. "Ethane dehydrogenation over pore - expanded mesoporous silica supported chromium oxide. Catalysis preparation and characterization."J. Mol. Catal. A. Chem., 2009, 301, 152-158.

[12] Rao, T.V.M. Zahidi, E. and sayari. A., "Ethane dehydrogenation over pore-expanded mesoporous silica supported chromium oxide. Catalytic properties and nature of active sites."J. Mol. Catal. A. Chem.2009, 301, 159-165.

[13] Wang, G. Zhang, L. Deng, J. Hai, H. He, H. and Tong C. "Preparation, Characterization and catalytic activity of Chromia supported on SBA-15 for the oxidative dehydrogenation of iso butane". Appl. Catal. A. 2009, 355, 192-201.

[14] D. Zhang, B.N. Popov, and R.E. White. "Electrochemical Investigation of $\mathrm{CrO}_{26.5}$ doped $\mathrm{LiMn}_{2} \mathrm{O}_{4}$ as cathode material for Lithium-ion batteries." J. Power Sources 1998, 76, 81-89.

[15] D. Zhang, P. Arora, B.N. Popov and R.E. White, "Processing, Structure, Property: Performance Investigations of Lithium Manganese-based Oxides for Li Rechargeable Batteries"J. Power sources. 1999, 83, 121-132.

[16] Texixeiva, V. Sousa, E. Costa, M.F. Nunes, C. Rosa, L. Carvalho. M.J. Collares - Pereira, M. Roman, E. and Gago J., "Spectrally selective compositive coatings of $\mathrm{Cr}-\mathrm{Cr}_{2} \mathrm{O}_{3}$ and $\mathrm{Mo}-\mathrm{Al}_{2} \mathrm{O}$ for solar energy applications". Thin solid films $2001,392,320-326$.

[17] M.D. Bijker, J.J.J. Bastiaens, E.A. Draasisma L.A.M. Jong, E. Sourty, S.O. Saied, J.L - Sullivan, "Synthesis and Investigation the Catalytic Behavior of $\mathrm{Cr}_{2} \mathrm{O}_{3}$ Nanoparticles". Tribol. Int.2003, 36227-233.

[18] J. Desilvestro, O. Haas, "Solid-state Sodium Batteries Using Polymer Electrolytes and Sodium Intercalation Electrode Materials" J. Electrochem. Soc.1990, 137, 58-65

[19] RaminKarimian, FaridehPiri, "Synthesis and Investigation of the catalytic behavior of $\mathrm{Cr}_{2} \mathrm{O}_{3}$ Nanoparticles".Journal of Nanostructures, 2013, 3, 87-92.

[20] Navid B. Saleh, Delia J. Milliron, NirupamAich, Lynn E. Katz, Howard M. Liliestrand, Mary Jo Kirisits, "Importance of doping, dopant distribution and defects on electronic band structure alteration of metal oxide nono particles. Implications for reactive oxygen species." Science of the Total Environment, $2016,568,926-932$

[21] R. Viswanantha, T.G. Venkatesh, C.C. Vidyasagar, Y. ArthobaNayaka, "Preparation and characterization of $\mathrm{ZnO}$ and $\mathrm{Mg}-\mathrm{ZnO}$ nanoparticle". Archives of Applied Science Research, 2012, 4 (1), 480-486.

[22] J. Zheng, Z.Y. Jiang, Q. Kuang, Z.X. Xie, R.B. Huang, L.S. Zheng, "Shape-controlled fabrication of porous $\mathrm{ZnO}$ architectures and their photocatalytic properties". J. Solid state Chem., 2009, 182, 115-121.

[23] M. Salavati - Niasari, N. Mir. F. Davar"ZnOnanotriangles: Synthesis, characterization and optical properties". J. Alloys Compd. 2009, 476, 908-912

[24] Dallinger, D. and Kappe. C.O. "Microwave Assisted Synthesis in water as solvent". Chem. Rev. 2007,107, 2563-2591.

[25] Dahd, J.A. Maddnx, B.L.S and Hutchison, J.E. "Toward greener nanosynthesis". Chem. Rev.2007, 107, 2228 - 2269.

[26] F. Farzanesh and M. Najafi, Journal of Sciences, Islamic republic of Iran, 2011, 22(4), 329-333. 